\title{
Local Foods Through Crisis
}

\author{
Hunter Heaivilin
}

One night in early April, I dreamt I was perusing the kalo shelf in a neighborhood market. A grocer ambled up and told me the flavor, color, and uses, of each corm in the array. Moi, Mana 'Ulu, 'Ula ula Kumu, Haokea, Lehua Maoli, Lauloa 'Ele'ele'ula and so on-all were organized by variety. When I woke, the night had ended, but this common dream has not.

Hawai i's farms are often motivated by the desire to reduce imports and feed communities, and consumer demand for many local products is greater than supply. However, increasing production doesn't necessarily decrease food insecurity in our communities, as fair farm gate prices too rarely meet the budget of the family down the street. The COVID-19 pandemic has demonstrated the economic precarity of farms and families. To build a more resilient Hawai $i$, we must address long-standing structural inequalities and systemic vulnerabilities in our food system. Fortunately, in this time of crisis, the opportunities for food system change are finding new purchase in the world that can be.

My adult life has been consumed with Hawai i's food system, but when growing up in the islands it was mostly invisible to me. Outside of a middle school afternoon trying poi with sugar or the occasional lū'au, my taste for local fare was mostly focused on musubi and plate lunch. After high school I graduated into gardening and agroforestry, enthralled with radical self-reliance as a means to change the world. Teaching permaculture took me across the islands and the tropics. Working with homesteads and farms at some point gave way to assessing zoning code and building market systems. Over a decade in, somehow my hands are now are softsoil supplanted by systems, planting by policy. The certainty of that young gardener has been replaced by the questioning of this $\mathrm{PhD}$ student. My doctoral research now focuses on the development of Hawai i's agrofood system and food crises we faced during the twentieth century. That historical lens informs my current work on our food system responses to the pandemic.

The pandemic disruption to Hawai i's food system is significant, but not as disordering as some previous crises. Eighteenth-century famines in the islands were driven by weather and warfare. Drought and battle decimated local production, causing starvation. In the early nineteenth century, economic factors shifted labor from agriculture to sandalwood, as the draw of a global market overwhelmed efforts at local production, producing famine (Rice). Over the next century, the 
global market grip grew tighter, as export agriculture and food imports both expanded. By the start of the twentieth century, most agricultural parcels, excepting plantation lands, were only five acres in size. Then in the century's first half, our food crises were again mostly driven by warfare.

During World War I and World War II, the narrowing supply coming into the islands created food system disruptions. For both wars a local governing body was formed to oversee pricing, allocate imports, and bolster local production. In the year prior to the start of WWI in April 1917, Hawai' $\mathrm{i}$ imported \$10,000,000 of mostly staple foods (Kuykendall and Gill). By May 1917, Hawai' i’s Legislature had created the Territorial Food Commission to govern production and conservation, and make the islands as "independent as possible of the mainland for subsistence." This broad ambit made it the "most powerful board ever created in the Islands" ("Territorial Food"). The commission addressed increasing the taro supply, supported a robust Women's Committee that performed statewide outreach, and funded county agents to work with small farmers, a service that then became part of UH Extension. Wheat flour shortages led to incorporating local starches into "war bread." The Banana Consuming Propaganda Committee redirected the oversupply of once exported fruit into local bakeries and homes, developing Hawai i's taste for banana bread that persists today.

By the late 1930s, sixty percent of fresh vegetables were being imported (Magistad and Frazier). Over the course of WWII, Hawai' $\mathrm{i}$ food administration changed hands from the Office of Civilian Defense's Food Control Board to the military Governor's Office of Food Control. The Food Control Board developed a plan to bolster rapidly declining taro production exacerbated by labor shortages. But in its efforts to address food conservation and price issues, the board was chided for not including women, who were responsible for " 90 per cent of the food purchased and prepared" ("Consumer Group"). As the conflict wore on, planning work became dominated by plantation interests, which wrongly assumed their industrial agriculture operations could easily transition to local food production. The grounding of offshore fishing fleets over fears of naval surveillance created a protein gap in local diets that Spam filled. Poke eventually returned, but Spam musubi has endured. After the war, only five percent of agricultural lands, in small parcels, were producing vegetable and fruit crops (Scheffer), and by the end of the decade, just over half of Hawai i's food was being imported (Yamaguchi). These wartime events reveal the complexity of food crisis management, and how our responses have shaped "local" food.

Spared so far from drought and war, today's food crisis is economic. Supply chains have remained intact, although mass unemployment has drastically diminished the purchasing power of most households. Initial pandemic disruptions of restaurants, hotels, and farmers markets have carved into the bottom line of farms across the state. New relationships between farms and food banks have become lifelines for farmers and families. New funding mechanisms - federal, state, county, 
and philanthropic - have supported these efforts. Food hubs connecting farms and buyers have seen surges in membership, routing unprecedented amounts of local fare onto family tables.

The open questions are about how durable these changes are. Will we, as in past crises, fill our plates with so much local produce that we will no longer dine without it? When funding wanes and we trudge back to work, will our palates have been transformed? More pointedly, how do we ensure that addressing hunger and supporting local agriculture aren't just crisis responses, but new realities?

As all food crises have shown, planning in food systems is crucial. Such efforts need to be comprehensive, inclusive, and both short and long term. Akin to previous food crisis committees, but without the broad powers of government, an Agricultural Response and Recovery Working Group formed in late March. We've worked to direct resources to keep farmers and ranchers afloat, connect local production to community feeding needs, and compile opportunities for growing the agricultural sector. Yet, for all of our work, Hawai'i's food system still must deal with systemic vulnerabilities and inequalities due to our geography and global market relations. For food system resilience and equity to transition from an appetizing idea to our main course of action, we must center both sustainability and justice in our economic planning. Two good places to start are cooperative development and living wages. We need cooperative mechanisms that enable farms to overcome the mismatch between their small parcel size and the global marketplace on our shelves.

We also need a living wage for all workers. Otherwise, local food will remain out of reach for too many.

Global discord and markets will continue to interweave with island lands, labors, and flavors to produce and reproduce place, people, and palates. The response decisions we make now, and the plans we set forth, will set the table for years to come. I have yet to see kalo arranged by variety in the grocery store, but in recent weeks two new poi pickups around my neighborhood have popped up.

Sure tastes like progress to me. So, when can, eat up Hawai' $i$. The poi is sweet.

\section{Works Cited}

"Consumer Group Agent is Urged." Honolulu Star-Bulletin, 21 Jan. 1942, p. 4.

"Food Commission Has Great Powers." The Maui News, 11 May 1917.

Kuykendall, Ralph S., and Lorin Tarr Gill. Hawaii in the World War. The Historical Commission, 1928.

Magistad, O. C., and T. O. Frazier. "Production and Marketing of Truck Crops in the Territory of Hawaii." Hawaii Agricultural Experiment Station, no. 78, April 1938.

Rice, Stian A. "Food System Reorganization and Vulnerability to Crisis: A Structural Analysis of Famine Genesis." 2018. Kent State University, PhD dissertation.

Scheffer, W. J. "Large Scale Farming in the Hawaiian Islands." Journal of ASFMRA, vol. 12, no. 1, 1948, pp. 70-79. 
“The Territorial Food Commission.” The Maui News, 11 May 1917, p. 4.

Yamaguchi, R. "Honolulu unloads fruits, vegetables, meats, dairy and poultry products, 1959.” Agricultural Extension Service, College of Agriculture, University of Hawaii, Agricultural Economics Report, no. 45, May 1960.

Hunter Heaivilin is a $\mathrm{PhD}$ student in the Department of Geography and Environment at the University of Hawai' $\mathrm{i}$ at Mānoa, and works as a food system planner at his firm Supersistence. 